\title{
Beyond Borders: Jean Gerson's Conciliarism in Late Medieval Spain
}

\author{
DARCY KERN \\ Southern Connecticut State University
}

In recent years there has been renewed interest in conciliarism, the belief that the authority of the universal church resides in an ecumenical council, not the pope, though the perception remains that conciliarism had a negligible impact in Iberia. One way to better understand the evolution of conciliar thought in the Spanish kingdoms is by looking at the circulation of the works and ideas of the French conciliarist Jean Gerson (1363-1429). Though a complete reconstruction of Gerson's circulation is impossible, one can offer an initial overview of his impact in the Spanish kingdoms not simply by counting manuscripts or incunabula, as valuable as that is, but by thinking broadly about networks of exchange and dissemination. Gerson's works came to Spain through the church councils, trans-Pyrenees Carthusian networks, monastic reformers, printers and printing houses, mendicant reformers, and the library of the University of Salamanca.

Ces dernières années, quoique le conciliarisme demeure généralement perçu comme ayant eu un impact négligeable sur la péninsule ibérique, l'on constate un intérêt renouvelé envers cette doctrine qui stipule que l'autorité de l'Église universelle ne résiderait pas dans le pape, mais bien dans un concile cecuménique. Une meilleure manière de comprendre l'évolution de la pensée conciliaire dans les royaumes espagnols serait d'étudier les œuvres et les idées du conciliariste français Jean Gerson (1363-1429). Bien qu'une reconstitution complète de la circulation de ce corpus s'avère impossible, une étude préliminaire de l'impact de Gerson sur les royaumes espagnols pourrait s'attacher non seulement à recenser ses manuscrits et ses incunables (une étude intéressante en soi), mais aussi s'intéresser plus largement aux réseaux d'échange et de dissémination de ses ouvres. Les ouvres de Gerson sont venues en Espagne par l'intermédiaire des conseils d'église, des réseaux chartreux transpyrénéens, des réformateurs monastiques, des imprimeurs et des imprimeries, des réformateurs mendiants et de la bibliothèque de l'Université de Salamanque.

\section{The two major church councils of the fifteenth century-Constance (1414-18) and Basel (1431-49)-included large Spanish (Castilian and Aragonese) delegations. ${ }^{1}$ Spanish theologians and jurists such as Juan de Segovia, Juan González de Sevilla, Alfonso de Madrigal ("El Tostado"), Alfonso de Cartagena, and Nicolò de' Tudeschi ("Panormitanus") attended at least one}

1. Delegates to the Council of Constance were divided into "nations." The Spanish "nation" consisted of Castilian, Aragonese, and Portuguese delegates. For the purposes of this article, the term Spanish indicates Castilian and Aragonese. 
council and contributed significantly to conciliarist theories. Despite their work and the fact that the conciliar period has received renewed attention in recent years, there is still a perception that conciliarism had a negligible impact in Spain because the problems in the church-benefices, taxes, jurisdiction, clerics-did not resonate as deeply or as politically as they did elsewhere and because the papacy made concessions to Spanish kings in order to maintain crusades in the peninsula and North Africa. ${ }^{2}$ Juan II of Castile (r. 1406-54) generally opposed conciliarism, which meant that the Castilian government was unlikely to encourage the widespread distribution of conciliar tracts. Alfonso V of Aragon (r. 1416-58) was better disposed towards it and was a long-time ally of Emperor Sigismund, a chief sponsor of conciliarism, but Alfonso's desire to control the western Mediterranean required papal support and thus some concessions to papalist government of the church. ${ }^{3}$

The perception that conciliarism had a negligible impact in Iberia, though not without merit, is inadequate. We still need a better understanding of the evolution of conciliar thought in the Spanish kingdoms in light of the texts that were written, copied, and circulated, and a greater awareness of the role played by fifteenth-century monastic and academic centres in articulating and spreading conciliarism. ${ }^{4}$ One way to do this is by looking at the circulation of the works and ideas of the French conciliarist Jean Gerson (1363-1429), who

2. E. Delaruelle, E.-R. Labande, and Paul Ourliac, eds., L'Église au temps du Grand Schisme et de la crise conciliaire (1378-1449), Histoire de l'Église 14 (Belgium: Bloud and Gay, 1962), 431. All translations are mine unless otherwise noted.

3. Christian Hermann, "Settlements: Iberia," in Handbook of European History, 1400-1600, ed. Thomas A. Brady, Jr., Heiko Oberman, James D. Tracy, vol. 2 (Leiden: Brill, 1995), 506. Alfonso's varied purposes manifested themselves in the work of Panormitanus, his ambassador to the Council of Basel, who wrote extensively in defense of the council, particularly in its deposition of Pope Eugenius IV, though he often had to contradict his own writings in the advice he gave the council. Michiel Decaluwé and Gerald Christianson, "Historical Survey," in A Companion to the Council of Basel, ed. Michiel Decaluwé, Thomas Izbicki, and Gerald Christianson (Boston: Brill, 2017), 29.

4. Antony Black has observed that from its beginning conciliarism "owed much to university men, and to the university environment; and during the [Council of] Basle [sic] the universities played an increasingly important part, both through their delegates, and by their independent action, in support of the Council." A. J. Black, Monarchy and Community: Political Ideas in the Later Conciliar Controversy, 1430-1450 (Cambridge: Cambridge University Press, 1970), 24. Hans-Jörg Gilomen also notes the importance of university men at Constance and, especially, Basel, where they accounted for a fifth of all participants. Hans-Jörg Gilomen, “Conciliar Bureaucracy," in A Companion to the Council of Basel, 180-81. 
attended Constance as a delegate for the king of France, the University of Paris, and the ecclesiastical province of Sens. ${ }^{5}$ Despite, or perhaps because of, the breadth of his writings and the varied circumstances in which he wrote over the course of his life, Gerson never really constructed a systematic theology but was "something of an eclectic improviser, structuring his conceptions according to the needs of the object in view." For this reason, it was relatively easy for his contemporaries to pick and choose which of his ideas they wanted to incorporate into their own philosophies. Though a complete reconstruction of Gerson's circulation is impossible because private libraries and texts have been lost, manuscript origins and exchange patterns cannot always be determined, and conversations often are untraceable, one can offer an initial overview of his impact in the Spanish kingdoms by thinking broadly about networks of exchange and dissemination. Gerson's works followed multiple paths to Spain: through the church councils, the trans-Pyrenees Carthusian networks, monastic reformers, printers and printing houses, mendicant reformers, and the library of the University of Salamanca.

Gerson was generally quite popular on the Continent, as D. Catherine Brown has observed: "Even before the end of the fifteenth century there had been six printed editions of his complete works apart from the numerous manuscripts and printed editions of single works or selected groups of his writings that were produced during the century." However, Daniel Hobbins

5. John Morrall, Gerson and the Great Schism (Manchester: Manchester University Press, 1960), 94.

6. John J. Ryan, The Apostolic Conciliarism of Jean Gerson (Atlanta: Scholars Press, 1998), 9. As Gerson matured, he wrote about a wide range of topics from mysticism to the role of women and gender in church and society, to biblical theology, to political and ecclesiastical government. He wrote not only for academics and theologians but also with a view toward teaching the public, both men and women. See Brian Patrick McGuire, "Jean Gerson and the Renewal of Scholastic Discourse, 1400-1415," in Knowledge, Discipline, and Power in the Middle Ages, ed. Joseph Canning, Edmund King, and Martial Staub (Boston: Brill, 2011), 142-43; Louis B. Pascoe, Jean Gerson: Principles of Church Reform (Leiden: Brill, 1973). Gerson's mystical tracts were popular and influential in the Iberian Peninsula. See Peter Tyler, "Mystical Affinities: St. Teresa and Jean Gerson," in Teresa of Avila: Mystical Theology and Spirituality in the Carmelite Tradition, ed. Peter Tyler and Edward Howells (New York: Routledge, 2017), 36-50; Jeffrey Fisher, “Gerson's Mystical Theology: A New Profile of Its Evolution," in A Companion to Jean Gerson, ed. Brian Patrick McGuire (Boston: Brill, 2006), 205-48; Nancy McLoughlin, Jean Gerson and Gender: Rhetoric and Politics in Fifteenth-Century France (New York: Palgrave Macmillan, 2015).

7. D. Catherine Brown, Pastor and Laity in the Theology of Jean Gerson (Cambridge: Cambridge University Press, 1987), 2. 
argues that Gerson was unpopular and unread in Spain because the number of manuscript copies of his work in the Spanish kingdoms is significantly smaller than those found in the lands of the Holy Roman Empire. Even after the advent of print in the 1450s, the number of Gerson's works in Spain accounted for only 3.1 percent of all printed editions, as compared to 32 percent for the empire, 21.4 percent for France, and 18.4 percent for Italy, though Hobbins rightly observes that book production in general in Spain never approached the level of book production in the empire before or after print. ${ }^{8}$ Hobbins's quantitative history is important, but sheer volume or popularity does not necessarily mean the texts were read, even if sold, just as unpopularity in terms of numbers printed or sold does not mean the extant copies were left unread and uncirculated. We cannot always measure books lent or borrowed, texts lost or destroyed, discussions among acquaintances, engagement with ideas perceived to be dangerous, and many other factors. ${ }^{9}$ Further, much of the print industry and book trade in the Spanish kingdoms was run by foreigners who concentrated on printing in Castilian rather than Latin or any other language. ${ }^{10}$ Since the presses in the German lands were already printing Gerson's Latin works, printers in Iberia may have seen no need for localized print runs.

Additionally, our understanding of textual circulation in Spain is incomplete because of the historic paucity of archival finding aids, particularly for local, regional, and private libraries and archives, though this has begun to change in recent years. A short-title catalogue of early printed works in Spain did not appear until 2010; scholars working before then had "to confront a highly fragmented picture of publishing on the Peninsula, exploiting disparate catalogues of collections, of places of publication, or of printing houses." Consulting a basic list of all works by a given author was nearly impossible, as were developing "reliable indications of how many books were produced"

8. Daniel Hobbins, Authorship and Publicity before Print: Jean Gerson and the Transformation of Late Medieval Learning (Philadelphia: University of Pennsylvania Press, 2009), 213.

9. For a summary of all unaccounted works from just one printing house-the Cromberger press in Seville-see F. J. Norton, Printing in Spain, 1501-1520 (1966; Cambridge: Cambridge University Press, 2010), 10.

10. María Luisa López-Vidriero, "History of the Book in the Iberian Peninsula," in The Book: A Global History, ed. Michael J. F. Suarez and H. R. Woudhuysen (Oxford: Oxford University Press, 2014), 412-13; Norton, 12. 
before 1600 or visualizing the broader landscape of Iberian publishing. ${ }^{11} \mathrm{~A}$ quick survey of the geographic distribution of early Gerson prints in Spain shows it was quite diffuse: Valencia, Burgos, Sevilla, Montserrat, Barcelona, Alcalá de Henares, Zaragoza, Toledo, even Palma de Mallorca and New Spain (Mexico). ${ }^{12}$ The picture becomes even more imprecise when one looks at manuscript production, particularly in a region such as the Crown of Aragon that, though Spanish according to modern borders, had strong cultural affinities with southern France.

The low numbers of identifiable Gerson texts made or printed in Spain do not necessarily signify that he and his conciliarist ideas were disregarded there. This is especially true for the Crown of Aragon, which had a thriving book trade and a king ambivalent towards conciliarism, though Castilians also read Gerson and incorporated his ideas on authority and government into their own. Influenced by Gilbert Ouy's important, ground-breaking work on the circulation of Gerson's manuscripts in France and among the French nobility captive in England in the fifteenth century, and by Daniel Hobbins's more recent research on Gerson's circulation in the German-speaking lands, ${ }^{13}$ this article argues that Gerson's works likely had a wider circulation among Castilians and Aragonese than scholars have previously allowed and that his political and ecclesiastical ideas influenced Spanish thought well into the sixteenth century.

In 1378, at the age of fourteen, Gerson left home to study first the arts then theology at the College of Navarre in Paris. ${ }^{14}$ Ten years later he took

11. Alexander Wilkinson, ed., Iberian Books: Books Published in Spanish or Portuguese or on the Iberian Peninsula before 1601 (Boston: Brill, 2010), viii. Wilkinson notes that the late date of 2010 for a shorttitle catalogue is "truly staggering."

12. Wilkinson, ed., 375.

13. Gilbert Ouy, La librairie des frères captifs: les manuscrits de Charles d'Orléans et Jean d'Angoulême (Turnhout: Brepols, 2007); Danièle Calvot et Gilbert Ouy, L'œuvre de Gerson à Saint-Victor de Paris: catalogue des manuscrits (Paris: CNRS Éditions, 1990); Gilbert Ouy, "Gerson et l'Angleterre: A propos d'un texte polémique retrouvé du chancelier Paris contre l'Université d'Oxford (1396)," in Humanism in France at the End of the Middle Ages and in the Early Renaissance, ed. A. H. T. Levi (Manchester: Manchester University Press, 1970), 43-81; Daniel Hobbins, "The Council of Basel and Distribution Patterns of the Works of Jean Gerson," in Religious Controversy in Europe, 1378-1536: Textual Transmission and Networks of Readership, ed. Michael Van Dussen and Pavel Soukup (Turnhout: Brepols, 2013), 137-70.

14. Brian Patrick McGuire, "In Search of Jean Gerson: Chronology of His Life and Works," in $A$ Companion to Jean Gerson, 4. 
part in a university mission to the papal court in Avignon. The university mission sought to counter the Dominican practice of denying the necessity of Mary's immaculate conception in general and Dominican theologian Juan de Monzón's denial of it in particular. The following year, Gerson wrote a tract, Adversus Joannem de Montesono, against Monzón. ${ }^{15}$ Ouy calls this his "first important work." ${ }^{16}$ In the tract, Gerson uses classical and patristic sources to refute the Castilian-founded Dominican Order and the Aragonese Monzón. ${ }^{17}$ His emphasis on French exceptionalism in the tract was common for him at the time. In a sermon he preached a few years later, he repeated St. Jerome's claim that "only Gaul has lacked monsters [e.g., heretics]." ${ }^{18}$ Early arguments such as these were unlikely to inspire Iberians (or anyone else, for that matter) to entertain Gerson's work, no matter how brilliant he was.

In 1394 Pedro Martínez de Luna, a member of an aristocratic Aragonese family, was elected Pope Benedict XIII as the Avignon claimant, in opposition to Pope Boniface IX, the Roman claimant. The University of Paris initially regarded Pope Benedict as an ally. In April 1395 Benedict appointed Gerson chancellor of the university, a position that gave him "an enormous intellectual and moral influence on his contemporaries and on the next generation." 19 As events progressed and the Roman and Avignon claimants became more intractable in their insistence on their own legitimacy, Gerson reflected more on the unity of the church, which he increasingly believed came from the whole rather than from the various parts, no matter how important the parts might

15. McGuire, "In Search of Jean Gerson," 6.

16. Gilbert Ouy, "La plus ancienne oeuvre retrouvée de Jean Gerson: Le brouillon inachevé d'un traité contre Juan de Monzon (1389-1390)," Romania 83 (1962): 434.

17. Brian Patrick McGuire, Jean Gerson and the Last Medieval Reformation (University Park: Pennsylvania State University Press, 2005), 42. McGuire describes the tract as one of "inflammatory rhetoric," "crass ridicule and scatological language," harshness, invective, passion, "much vindictiveness," and an absence of self-discipline, understanding, or sympathy (46-47). Gerson cites Jerome, Sallust, Vergil, and others. Jean Gerson, Oeuvres complètes, ed. Palemon Glorieux, vol. 10 (Paris: Desclées, 1960-73), 7. See also Gilbert Ouy, "Humanism and Nationalism in France at the Turn of the Fifteenth Century," in The Birth of Identities: Denmark and Europe in the Middle Ages, ed. Brian Patrick McGuire (Copenhagen: Reitzel, 1996), 108-11.

18. McGuire, Jean Gerson and the Last Medieval Reformation, 49; Gerson, Oeuvres complètes, 10:10.

19. Antony Black, Council and Commune: The Conciliar Movement and the Council of Basle (London: Burns and Oates, 1979), 19. See also McGuire, "In Search of Jean Gerson," 8. 
be. He expounded on this idea in Tractatus de unitate ecclesiae, written the same year (1409) that the Council of Pisa met to end the papal schism.

Around the time Gerson wrote De unitate ecclesiae, he also began to write more about the papal exercise of temporalities, suggesting that although the pope has dominion over worldly goods, his dominion should be "removed for a time or suspended" from his use. ${ }^{20}$ John Ryan observes that Gerson did not take this argument to the radical ends that the Spiritual Franciscans did, in that he did not recommend that the pope relinquish all ownership of material goods, but even in his moderation Gerson nonetheless recommended that the pope cease exercising his fullness of ownership. ${ }^{21}$ As a theologian, Gerson also began to advocate for a return to "evangelical law" in place of continued adherence to canon law. He viewed canon law as an institutional, human system rather than a biblical one, though he did cite it when it served a purpose. By the time of the Council of Constance, Gerson explicitly complained about the multiplication of constitutions, that is, legal systems, within the church, because they distracted and hampered the church from being what God intended-the congregatio fidelium mystically united (as a whole) to Christ. ${ }^{22}$

In addition to multiple constitutions, there were multiple popes-three from 1409 onwards. Gerson increasingly regarded Benedict, who refused to resign his office and reunify the church, as a barrier to ending the schism, and sought to provide intellectual support for his deposition. ${ }^{23}$ In April 1415, just weeks after his arrival at Constance, Gerson had his work De auferibilitate

20. Gerson, Oeuvres complètes, 6:55-56. From De concilio unius obedientiae. For the translation, see Ryan, 33.

21. Ryan, 34. If we accept Ryan's contention that Gerson's conciliarism was, at root, a "vision of the Church as an apostolic gathering," that is, as the early church of the Scriptures (24), Gerson's influence on Spanish thought, particularly among the Franciscans and their associates, is more pronounced. (Emphasis in the original.) David Zachariah Flanagin's work supports Ryan's contention that Gerson's conciliarism was grounded in Scripture and the early experience of the church in fraternal correction and decision making, though Flanagin criticizes Ryan's interpretation of Gerson as "inspired by the vague, late medieval tradition of 'apostolic protest." David Zachariah Flanagin, "God's Divine Law: The Scriptural Founts of Conciliar Theory in Jean Gerson," in The Church, The Councils, and Reform, ed. Gerald Christianson, Thomas Izbicki, and Christopher Bellitto (Washington, DC: Catholic University of America Press, 2008), 101-21.

22. Gerson, Oeuvres complètes, 3:163, 299, 5:228, 439, 6:102. See also Flanagin, 102-03.

23. The Spanish "nation" arrived late to the Council of Constance because they supported Benedict XIII as pope. Alfonso V of Aragon protected Luna until the latter's death in 1423. Philip H. Stump, The 
papae ab ecclesia (On the removability of the pope from the church, 1409) publicly pronounced at a Dominican convent. The text gave numerous reasons why the universal church could remove a pope. Gerson argued that the church, as a corpus mysticum, "always maintained its intrinsic unity even in the absence of an earthly head through adhesion to its true head, Christ." ${ }^{24}$ The pope, as the purported heir to the apostle Peter, is head of the faithful as Christ's earthly representative, but he himself is not the true head. Because of Christ's headship, the congregatio fidelum could never truly be acephalous. ${ }^{25}$ Further, not only was Christ the head of the church, he was the true spouse of the church. His marriage to the church was indissoluble. ${ }^{26}$ The Holy Spirit, as Christ's spirit, maintained this marriage and the unity of the mystical body of the church. ${ }^{27}$ The unity of the corpus mysticum meant that the universal church had oversight over exclusively human individuals no matter how important the individuals might be. Gerson wrote, "The church or a council representing it can institute or elect or designate the pope." ${ }^{28}$ The pope's headship of the church is secondary to that of Christ. Though God instituted the papal office, the particular individual who holds the office is chosen by men who represent the corpus mysticum.

A month after De auferibilitate papae appeared, the Council of Constance deposed Pope John XXIII (r. 1410-15), the Pisan claimant to the papal throne. In order to further assist the council in its attempts to remove Benedict XIII and restore unity to the church, Gerson wrote a legal tract entitled Libellus

\footnotetext{
Reforms of the Council of Constance: 1414-1418 (Leiden: Brill, 1993), 38. See also Louise R. Loomis, "Nationality at the Council of Constance," The American Historical Review 44:3 (1939): 508-27.

24. Jean Gerson, De auferibilitate papae ab ecclesia (Paris: Ulrich Gering, Martin Grantz, Michael Friburger, ca. 1474-77) [Beinecke 1971 753], f. 1r. Gerson cites Ephesians 4 and Colossians 1 to prove Christ's headship of the body. For the translation, see Tierney, Religion, Law, and the Growth of Constitutional Thought, 92 .
}

25. Gerson, De auferibilitate papae [Beinecke 1971 753], f. 1r.

26. Gerson, De auferibilitate papae [Beinecke 1971 753], ff. 1v-4v. Gerson frequently refers to John and the Book of Revelation (which he calls Apocalypse) to prove Christ's marriage to the church. Each of his first seven considerations in De auferibilitate papae refers to Christ as the spouse of the church. At the conclusion of the work he writes that it is impossible to remove the church's spouse (f. 16v).

27. Gerson, De auferibilitate papae [Beinecke 1971 753], f. 2v. Gerson argued a similar point about the Holy Spirit's authority in his sermon Ambulate dum lucem habetis, given before the Council of Constance on 23 March 1415. Gerson, Oeuvres complètes, 5:44. See also Natacha-Ingrid Tinteroff, "The Councils and the Holy Spirit: Liturgical Perspectives," in The Church, The Councils, and Reform, 140-54. 28. Gerson, De auferibilitate papae [Beinecke 1971 753], f. 4r. Emphasis added. 
articulorum contra Petrum de Luna. He also wrote his most well-known treatise on ecclesiastical power, De potestate ecclesiastica et de origine iuris et legum, based on his lectiones of 1402 and read publicly at Constance in February 1417. De potestate ecclesiastica addressed the topics of divine law, natural law, human law, and the life of the soul, post-baptism, under the guidance of the Holy Spirit. ${ }^{29}$ Gerson argues in thirteen "considerations" that the hierarchy of the church-papacy, cardinalate, patriarchate, archiepiscopate, episcopate, and priesthood-represents a sort of corporation that is responsible for the transmission of salvation to all believers within the mystical body of the church. ${ }^{30}$ Plenitude of power in such a corporation lies in the whole body of the membership. This power comes immediately from the Triune God, not through the pope as intermediary and constituent part of the whole. A council representing the whole church through the hierarchy confers power on individual office holders, thus regulating the pope's power, though in practice ideally only in extenuating circumstances. ${ }^{31}$ De potestate ecclesiastica was based on the writings of earlier curialists, including the Franciscan Alvarez Pelayo (d. 1350), confessor to Pope John XXII, and therefore not the radical tract papalists portrayed it as, ${ }^{32}$ though it did help legitimize the council's actions against papal claimants. On June 5, the council exercised its plenitude of power and declared Benedict XIII a heretic. On July 26, it deposed him in absentia. ${ }^{33}$

Gerson's influence on Spanish reformers began at the councils themselves. The Castilians and the Aragonese sent large official delegations to the Council of Basel in 1434, but before the former arrived several important figures, including Juan de Segovia, a theologian representing the University of Salamanca, and Juan

29. G. H. M. Posthumus Meyjes, Jean Gerson, Apostle of Unity: His Church Politics and Ecclesiology, trans. J. C. Grayson (Boston: Brill, 1999), 231; McGuire, "In Search of Jean Gerson," 26.

30. Posthumus Meyjes, 289.

31. Gerson, Oeuvres complètes, 6:232-33. This is in consideration eleven. See also Francis Oakley, The Conciliarist Tradition: Constitutionalism in the Catholic Church, 1300-1870 (Oxford: Oxford University Press, 2003), 80; Posthumus Meyjes, 291.

32. Posthumus Meyjes, 248-49. In spite of Gerson's belief that the church could depose a pope, he was "a cautious and conservative theologian." Francis Oakley, "Gerson as Conciliarist," in A Companion to Jean Gerson, 179.

33. McGuire, "In Search of Jean Gerson," 26. Several years before the council met, Benedict XIII retreated to the safety of Catalonia. He persisted in his papal claims until his death. 
González, bishop of Cádiz (1426-40), were already in attendance. Like Segovia, González was affiliated with the University of Salamanca, the only reference university in Castile at the time and thus the centre of intellectual study and exchange. ${ }^{34}$ González was among the first to swear an oath of incorporation to the council and was assigned to the deputacione pro reformatorio. ${ }^{35} \mathrm{He}$ was actively involved in investigating Eugenius IV's claim to the papacy and wrote a tract entitled Allegationes de potestate concilii factae tempore dissolutionis concilii Basielien prior to the arrival of the official contingent. In it he listed reasons for conciliar legitimacy:

First, the fullness of power is most complete in the universal church, just as it was in the beginning of the church. Second, the power of the council is from God. Third, the fullness of power is in the pope who is not in error; but if he errs, the general council can correct his faults. Finally, a general council is not subject to positive law. ${ }^{36}$

González's Allegationes de potestate concilii closely echoes Gerson's De potestate ecclesiastica in arguing that the power of the universal church, especially in extraordinary circumstances, is expressed through a council which represents it, and that a council's authority comes from the Triune God. Like Gerson he also minimized the role of canon law as a basis for church authority. It is clear that González was familiar with Gerson's work, which was copied and circulated at the council between 1433 and 1437.

Juan de Torquemada (d. 1468), arguably the most vociferous advocate of papal power in the fifteenth century, purchased one of these copies of $D e$

34. José María Monsalvo Antón, "Poder y cultura en la Castilla de Juan II: Ambientes cortesanos, humanismo autóctono y discursos políticos," in Salamanca y su universidad en el Primer Renacimiento: siglo XV, ed. Luis Enrique Rodríguez-San Pedro Bezares, and Juan Luis Polo Rodríguez (Salamanca: Ediciones Universidad, 2011), 70-71.

35. Pedro Carillo de Huete, Croníca Halconero de Juan II, ed. Juan de Mata Carriazo (Madrid: EspasaCalpe, 1946), 152.

36. Vicente Beltrán de Heredia, Cartulario de la Universidad de Salamanca (Salamanca: Secretariado de Publicaciones de la Universidad, 1973), 1:295. "Prima est quod plenitude potestatis plenitude est in ipsa ecclesia seu universitate ecclesiae tamquam in fundamento. Secunda est quod potestas concilii est a deo. Tertia quod potestatis plenitude est in ipso papa ita quod non erret; si tamen errat, hujusmodi errores corrigert concilium generale. Quinta conclusion quod generale concilium non subjicitur juri positive ut dictum est." 
potestate ecclesiastica at the council in $1437 .{ }^{37}$ Thomas Izbicki argues that Torquemada, a Dominican theologian, bought it because it "represented the quintessential statement of conciliarist thought," ${ }^{38}$ which would also explain González's familiarity with it. That Gerson and his conciliarism were subsequently held to be radical, rabid challenges to church authority was due in large part to Torquemada, who asserted that conciliarism was beholden to the anti-papal imperialist Marsilius of Padua (d. ca. 1342), even though Gerson explicitly reputed Marsilian views as heretical. ${ }^{39}$ Torquemada may have been influenced in his conclusions by men such as Simon de Plumetot (d. 1443), a Norman admirer of Gerson who had had De potestate ecclesiastica copied and bound with Marsilius's Defensor pacis and Herveus Natalis's Tractatus de iurisdictione ecclesiasticae potestatis seu de potestate papae shortly after the Council of Constance. ${ }^{40}$

It is unlikely that Torquemada's copy of De potestate ecclesiastica had much influence on the Spanish beyond the Council of Basel since he spent most of his time in Italy after purchasing it. However, another copy of De potestate may have been accessible to Spaniards. This is Beinecke Library Marston MS 264. Neither Hobbins, in his Index of Gerson's manuscripts, nor Palemon Glorieux, in his Complete Works of Gerson, which Hobbins observes is incomplete, lists this manuscript of De potestate ecclesiastica. ${ }^{41} \mathrm{~W}$. H. Bond identifies it as

\section{Hobbins, Authorship and Publicity before Print, 205.}

38. Thomas Izbicki, "Ecclesiological Texts of Jean Gerson and Pierre d'Ailly in Vatican Manuscript Collections Other Than the Codices Vaticani Latini," Manuscripta 33:3 (1989): 205. Torquemada's manuscript is now Vatican City, BAV, Vat. lat. 4117. See also Thomas Izbicki, Protector of the Faith: Cardinal Johannes de Turrecremata and the Defense of the Institutional Church (Washington, DC: Catholic University of America Press, 1981); G. Matteo Roccati, "Manuscrits de la Bibliothèque Vaticane contenant des oeuvres de Gerson: Compléments à l'édition Glorieux," Scriptorium 36 (1982): 103-11. The University of Pennsylvania's Schoenberg Collection has a copy of De potestate ecclesiastica, bound with several other tracts, from the monastery of Santa Scolastica in Subiaco, Italy ca. 1450 (SDBM_111930). Torquemada was abbot of the monastery from 1456.

39. For Gerson's position on Marsilius, see Gerson, De auferibilitate papae [Beinecke 1971 753], f. 5r. For Torquemada's position, see Juan de Torquemada, Summa de ecclesia (Venice: Michaelem Tramezinum, 1561), f. 169v. See also Oakley, "Gerson as Conciliarist," 181; Ryan, 56.

40. Danièle Calvot and Gilbert Ouy, L'oeuvre de Gerson à Saint-Victor de Paris (Paris: CNRS, 1990), 59-60; Yelena Mazour-Matusevich, “Gerson's Legacy," in A Companion to Jean Gerson, 383.

41. Hobbins, Authorship and Publicity before Print, 313-16; Gerson, Oeuvres complètes, 6:xv; Hobbins, "The Council of Basel," 137n1. According to Hobbins, the manuscripts listed in Glorieux's edition of the 
"written in France" in the fifteenth century. ${ }^{42}$ Barbara Shailor suggests that the binding and writing are fifteenth-century Spanish, from about 1450, though there is a possibility it was made in Southern France. It is bound envelopestyle with holes for ties to wrap around it and in thick, limp parchment sewn with two pink and one green tawed skin supports. A single scribe writing in a humanistic script copied the text, though a different hand appears to have written the title at the beginning and a few collation notations throughout. ${ }^{43}$ The book begins with a "crude," "asymmetrical" red initial, with flowers in the same colour at the conclusion of the prologue. ${ }^{44}$ It is clear that someone read the text and intended others to read it because someone included marginal notes to guide the reader throughout and corrected or marked words for deletion. For example, "plur" is crossed out on f. 32r. Though it is difficult to pinpoint exactly where the manuscript was made or who wrote it, it appears to be Spanish for several reasons. The asymmetry of the opening initial is suggestive of Spanish book production. The ruling of the marginal notes is not as precise as that done in one of the Bibliothèque nationale de France's (BnF) copies, though the text nonetheless was ruled for marginalia. The initial letters, such as the majuscule "P" (f. 1r, 2r, 3v, 5r, 7r, 8v, etc.), are typically Spanish in design. ${ }^{45}$ The "a"s throughout the text have "hats," while the "v"s and majuscule "s"s lean back, both common characteristics of Spanish hands. ${ }^{46}$

Complete Works "do not represent even half of the actual total."

42. W. H. Bond, ed., Supplement to the Census of Medieval and Renaissance Manuscripts in the United States and Canada (New York: Bibliographical Society of America, 1962), 95.

43. Albert Derolez has argued that the councils of Constance and Basel were the first large-scale occasions to bring together Italian writers using humanistic script and other European scholars who learned it from them. He specifically cites Gerson's own handwriting as showing marked Italian influence. Albert Derolez, The Paleography of Gothic Manuscript Books: From the Twelfth to the Early Sixteenth Century (Cambridge: Cambridge University Press, 2003), 180.

44. Barbara Shailor, Catalogue of Medieval and Renaissance Manuscripts in the Beinecke Rare Book and Manuscript Library, vol. 3 (Binghamton, NY: Medieval and Renaissance Texts and Studies, 1992), 519.

45. For similar examples of the red-lettered majuscule "P," see Vincent Ferrer, Sermones (Spain, 14501500) [Beinecke Marston MS 95], ff. 30r, 31v, 45r, 47r, and 48r.

46. Other examples of "v"s that lean back can be found in a rare copy of Giovanni Boccaccio's Decameron in Catalan, finished at Sant Cugat del Vallès in 1429, and Les Històries Troyanes de Guiu de Colmpnes, translated into Catalan by Bartolomé Miquel in Barcelona in 1433. Agustín Millares Carlo, Tratado de Paleografía Española (Madrid: Espasa-Calpe, 1983), 1:216-17, 2:276-77. Majuscule "s"s that lean back are common in manuscripts from northeast Spain and southwest France. See, for example, part 2 
The text itself differs from the "correct" or "standard" text in the Complete Works and also from the earliest printings of the work made in the German lands and Paris, which suggests that it does not follow the German manuscript stemma but rather one remote from the imperial lands. Further, it differs from the manuscripts in the BnF, some of which belonged to Parisian churches such as Notre Dame, again suggesting a distinct genealogy. ${ }^{47}$ For example, in the second line of the text, the Marston scribe has written "cognosci" instead of "agnosci". 48 The latter word is used in Plumetot's text as well as in all manuscript copies in the BnF and the early printings of Gerson's works, such as Guy Marchant's ca. 1484 single volume and the various collected editions. ${ }^{49}$ Sometimes the order of whole phrases is distinct. For example, the Marston manuscript reads "Alterum pestifera adulacione suspectum," whereas the BnF manuscripts and the incunabula state, "Alterum de adulacione pestifera suspectum est." Sometimes single words are reversed. For example, one finds "de ecclesiastica potestate" and "sit occulus intentionis" in the Marston manuscript and "de potestate ecclesiastica" and "sit intentionis occulus" in BnF Latin 3126 and the incunabula, though the first phrase does read the same in the Marston MS and in BnF Latin $17489 .{ }^{50}$ Nonetheless, the Marston colophon gives the correct date for De potestate's original publication (17 February 1417).

The stylistic nuances and textual differences lead one to conclude that Marston MS 264 was produced in a regional centre of production such as the

(ff. 47-168) of Calendar; Martyrology; Benedictine Rule (Southwestern France, 1100-1600) [Beinecke Marston MS 25]; Ferrer, Sermones [Marston 95], ff. 69r, 94r, 95r, 118v, 121v, 148r, 150r, 191v, 213v, 244r, and 292r.

47. Johannes Gerson, Opuscula $\left(\mathrm{xv}^{2 / 4}\right)$, BnF MS Latin 17489, which was made around the same time as Marston 264, is a cleaner copy with better initial letters and writing. It was made for the library of Notre Dame in Paris. See Bibliothèque nationale de France, Gallica, "Johannes Gerson, Opuscula," accessed 11 April 2018, gallica.bnf.fr/ark:/12148/btv1b8593565s.r=17489?rk=42918;4.

48. Beinecke Marston MS 264, f. $1 \mathrm{r}$.

49. Johannes Gerson, De potestate ecclesiastica et De origine juris et legum tractatus (s. xv), Bibliothèque nationale de France (BnF) MS Latin 3126, f. 62v; Gerson, Opuscula, BnF MS Latin 17489, f. 1r; Jean Gerson, De ecclesiastica potestate et De origine juris et legum tractatus (Paris: Guy Marchant, ca. 1484) [Beinecke 1971 742], f. a2r; Jean Gerson, Opera, vol. 1 (Nuremberg: Georg Stuchs, 1489) [Beinecke Zi 2263; Biblioteca Nacional de España (BNE) INC/2358], f. g6r; Jean Gerson, Opera, vol. 1 (Strassburg: Johann Grüninger (?), 1488) [Beinecke Zi +450.3], f. h1r.

50. Beinecke Marston MS 264, f. 1r; BnF MS Latin 3126 f. 63r; BnF MS Latin 17489, f. a2r; Gerson, Opera [Beinecke Zi 2263; BNE INC/2358], 1:g6r; Gerson, Opera [Beinecke Zi +450.3], 1:h1r. 
Cathedral Chapter of Barcelona, which has a 1415 copy of De auferabilitate papae that was bound with other conciliar tracts. ${ }^{51}$ Other possibilities are a Carthusian house or a Benedictine house, though these are less likely because their exchange networks extended into the German territories, giving them access to the German stemma as well as to Gerson's personal library housed at Grande Chartreuse. ${ }^{52}$ Gerson was particularly close to the Carthusians and asked the monks of Grande Chartreuse to edit and copy some of his writings. ${ }^{53}$ The Carthusians had been deeply affected by the papal schism. From 1410 to 1419 a group of mostly Spanish brothers led by the Valencian Boniface Ferrer (1350-1417) continued to support Benedict XIII even as Gerson's support for him waned. ${ }^{54}$ Two years after Ferrer died, Franciscus Maresme negotiated terms for him and his fellow dissidents to return to the order. Maresme then served as prior for several Spanish charterhouses until he became co-adjutor with Guillelmus de Mota of Grande Chartreuse in $1431 .{ }^{55}$ In 1440, under Maresme's leadership, the Carthusian general chapter wrote to the Council of Basel that they were sending four priors to render the order's obedience to the council and its elected pope, Felix V. The decision was not without controversy,

51. Hobbins, Authorship and Publicity before Print, 195-96, 285n92. The manuscript is Barcelona, ACC, Cod. 11. Hobbins calls it a "rare Spanish manuscript" of Gerson's works.

52. McGuire, Jean Gerson and the Last Medieval Reformation, 320, 324. Gerson originally intended to send his library to the Celestine monastery in Avignon, but he appears to have changed his mind at the end of his life and sent it to Grande Chartreuse instead.

53. McGuire, Jean Gerson and the Last Medieval Reformation, 312, 314. Gerson was also close to the Celestines; his brother was prior of the Celestine monastery in Lyon, France.

54. Santiago Cantera Montenegro and Margarita Cantera Montenegro, La Orden de la Cartuja en Andalucía en los siglos XV y XVI (Salzburg: University of Salzburg, 2005), 9-12. Ferrer translated the Vulgate into Valencian. It was printed in 1478 for the Valencian Philip Vizlant by the Castilian Alfonso Fernández de Córdova and the German Lambert Palomar. Today only its colophon exists in the Hispanic Society of America (ISTC ib00622000). Ferrer also wrote a tract, De schismate Pisano, challenging the acts of the Council of Pisa, which he attended. Santiago Cantera Montenegro, Los Cartujos en la Religiosidad y la Sociedad Españolas: 1390-1563 (Salzburg: University of Salzburg, 2000), 114.

55. William Lundell, "Bartholmeus van Maastricht on Carthusian Allegiance and Unity during the Basel Schism," in Religion, Text, and Society in Medieval Spain and Northern Europe, ed. Thomas Burman, Mark Meyerson, and Leah Shopkow (Toronto: Pontifical Institute of Medieval Studies, 2002), 250-74, $253-54$. 
particularly among Italian Carthusians,${ }^{56}$ but the order remained loyal to the Council of Basel until its dissolution in 1449. ${ }^{57}$

Gerson wrote a work, De contractibus (1421), at the behest of Grande Chartreuse, which was involved in apparently usurious commercial transactions at the time. ${ }^{58}$ Shortly after finishing it, he revised it. In the revision, he argued that human rules and regulations in the church, such as some of those covering commercial transactions, should be abolished whenever they are not observed..$^{59}$ De contractibus survives in more than sixty manuscripts, including one that belonged to the Benedictine monastery of Sant Cugat del Vallès, ${ }^{60}$ the most important monastery in the county of Barcelona and a centre of manuscript production. ${ }^{61}$ Its abbot, Estruch, participated in the Council of Basel. Though not a conciliar work, De contractibus does give an indication of networks of exchange between the Carthusians and other reforming orders, especially the Benedictines. ${ }^{62}$ Like the Beinecke's Marston manuscript of De potestate ecclesiastica, Sant Cugat's De contractibus is not listed in Hobbins or Glorieux. ${ }^{63}$ The manuscript, on paper, is plain and unfinished (the capital initials were never drawn in). It also has words corrected or marked for deletion. For example, on f. 1v "alia" is marked through while "civilis" has dots under it

56. Lundell, 256-57.

57. Lundell, 268.

58. Hobbins, Authorship and Publicity before Print, 60.

59. Hobbins, Authorship and Publicity before Print, 243n47; Posthumus Meyjes, 236.

60. Jean Gerson, Opusculum [de contractibus], Archivo de la Corona de Aragón (ACA), MS Sant Cugat 43. Sant Cugat had another manuscript (MS 1164) of Gerson's work, a compilation of his sermons and letters, in its library. Francisco Miquel Rosell, Catàleg dels llibres manuscrits de la biblioteca del Monestir de Sant Cugat del Vallès existents a l'Arxiu de la Corona d'Aragó (Barcelona: Casa de Caritat, 1937), 382-85.

61. In 1403 King Martí of Aragon asked the abbot of Sant Cugat to lend him his illuminator to finish some stories in the king's breviary. Martís letters suggest he actively encouraged the production and exchange of books. Antoni Rubió y Lluch, ed., Documents per l'historia de la cultura catalana mig-eval (Barcelona: Institut d'estudis catalans, 1908), 424.

62. Daniel Hobbins has noted this for the German lands but not the Spanish ones, in Authorship and Publicity before Print, 191. His research shows that Gerson was particularly popular among the Benedictine abbeys in the German-speaking lands, particularly those at Melk and Aggsbach, and that Gerson stimulated or contributed to the monastic reform of the fifteenth century. Hobbins, "The Council of Basel," 144-46.

63. Hobbins, Authorship and Publicity before Print, 313-16. 
because the scribe made a mistake; he repeated words from the previous line and had to mark them out. ${ }^{64}$ The scribal hand for this text is decidedly unSpanish and more likely German, which is not surprising since it is bound with Henricus Totting de Oyta's Tractatus de contractibus censualium. ${ }^{65}$

The fact that Sant Cugat owned a copy of De contractibus is important and suggests that the Benedictines as well as the Carthusians in southern France and the Crown of Aragon facilitated a book trade across the Pyrenees with a network extending into the heart of the German-speaking lands. This network helped to spread Gerson's texts across borders, including some of his most well-known and controversial writings. This network remained after the advent of print, extended by German printers and paper merchants. In 1498 Johann Luschner, a German printer, began working for the Benedictine Abbey of Montserrat, near Sant Cugat. Over the next three years Luschner printed extensively for its Castilian abbot, Garcia Ximenez de Cisneros, "who was acting as the representative of the entire Congregation of Valladolid," one of the Castilian Crown's most important cities. Among the texts Luschner published was Gerson's Epistola incitativa ad spiritualem profectum (1500). ${ }^{66}$ His print runs were considerable at eight hundred copies, ${ }^{67}$ and his contracts with the abbey indicate that half of his paper was to be purchased from two German merchants

\section{Gerson, Opusculum, ACA MS Sant Cugat 43, f. $1 \mathrm{v}$.}

65. At one time MS Sant Cugat 43 was bound with MS Sant Cugat 42, containing Francesc Eiximenis, Tractat d'usura and Quaestio disputata inter fr. Bernardum de Podio Cercoso et Raimundum de Area de licitudine contractus emptionis et venditionis cum conditione revenditionis, though MS 43 and MS 42 are written in different hands. Agustín Millares Carlo observes that because of the relatively quick German adoption and spread of humanistic script, there are excellent early Catalan examples of it, particularly in Latin texts, though I would argue that the Crown of Aragon's Neapolitan possessions also facilitated the spread of humanistic script, especially through scribes such as Giacomo Curlo. One of the examples Millares Carlo gives is Jean Gerson's Decem considerations super material celebrationis missarum, found in Biblioteca Nacional de España 4292, ff. 97r-107r. He also notes that when humanistic script reached is apogee in the mid-fifteenth century, it was adopted by early typographers in Italy, especially Conrad Sweynheym and Arnold Pannartz, who first worked at the Benedictine monastery of Subiaco, called there by Juan de Torquemada. Millares Carlo, Tratado de Paleografía Española, 1:218.

66. Norton, 100-01, 108; Falk Eisermann, "A Golden Age? Monastic Printing Houses in the Fifteenth Century," in Print Culture and Peripheries in Early Modern Europe, ed. Benito Rial Costas (Boston: Brill, 2012), 63.

67. Konrad Haebler, The Early Printers of Spain and Portugal, vols. 4-6 (London: Bibliographical Society, 1897), 77. 
in Barcelona, and half of it from two Catalan merchants, Mosén Aguilar and Pedro Camps. ${ }^{68}$ When one of the German merchants, Johann Trincher, is next found in the records (1512), he has ordered a Spanish arithmetic book to be printed by Nicholas de Benedictis in Lyons, France, again indicating the frequency with which books and ideas moved about in this period.

The other principal means of Gersonian transmission were the library at the University of Salamanca and mendicant reformers. At the Council of Basel, Juan de Segovia was seated next to the delegates from the University of Paris, an arrangement he appreciated because of his intellectual and scholarly affinity with them and their former chancellor. ${ }^{69}$ Segovia owned at least two copies of Gerson's De unitate ecclesiae, which, like De potestate ecclesiastica, proved a foundational text for him and other reformers. ${ }^{70}$ Segovia donated his library, including the two copies of De unitate ecclesiae, to the University of Salamanca when he died in 1458. Like the Cathedral Chapter of Barcelona's 1415 copy of De auferabilitate papae, Segovia's two copies of De unitate ecclesiae are bound with other conciliar tracts. The first, from 1442, is bound with texts by authors such as Panormitanus, a Benedictine, archbishop of Palermo, and royal representative to the council; Francesco Zabarella; Peter of Ancarano, a Carthusian doctor; and Segovia himself. The other is bound with Zabarella's and Ancarano's treatises from Pisa as well as works by Panormitanus. ${ }^{71}$

Segovia's bequest of his library to the University of Salamanca had longterm implications for the spread of Gerson's conciliar thought. Even the books in his library whose titles indicate that they had little or nothing to do with conciliarism often had a direct or indirect relationship to the topic because of Segovia's extensive annotations. ${ }^{72}$ Further, the library at Salamanca had at least one copy of González's Allegationes de potestate concilii. ${ }^{73}$ Succeeding

68. Haebler, 32.

69. Black, Council and Commune, 119.

70. Benigno Hernández Montes, Biblioteca de Juan de Segovia (Madrid: CSIC, 1984), 97, 105.

71. Hernández Montes, 24-25. The first manuscript copy of De unitate ecclesiae is numbered 58 in Hernández Montes's catalogue (Hernández Montes, 49). The second manuscript copy, numbered 89 in Hernández Montes's catalogue, is still extant in the library at Salamanca (Hernández Montes, 49).

72. Hernández Montes, 62-63.

73. Antonio Garcia y Garcia, "Juristas salmantinos, siglos 14-15: manuscritos e impresos," in Historia de la Universidad de Salamanca. Volumen III: Saberes y confluencias, ed. Luis Enrique Rodríguez-San Pedro 
generations of reformers studied at Salamanca, and some encountered Gerson there. Benigno Hernández Montes argues that the Segovian library had a greater affinity with the Franciscan and Augustinian schools than with the Dominican-Thomist school and thus inspired Franciscan reformers throughout the century, ${ }^{74}$ but Annabel Brett has shown that Gerson also influenced the sixteenth-century Dominican school of Salamanca's ideas on natural right and power. ${ }^{75}$ Beyond these schools, the Salamancan library influenced jurists such as Vasco de Quiroga, who worked closely with reforming Franciscans in New Spain (Mexico) in the sixteenth century.

The Franciscans, especially in Spain, sought church reform through a council in the latter half of the fifteenth century, just as Segovia and González had done earlier. Stimulated in part by Spiritual Franciscan calls for change in the previous century, the Franciscans looked to ecumenical church councils to reform clerical abuses, such as absenteeism, and the curial bureaucracy and finances, but in this they were frustrated, as the councils had to focus on the papal schism, not church reform. ${ }^{76}$ Though the Franciscans failed to reform the universal church, they were able to enact reforms in the Castilian church through a series of national church assemblies at Aranda (1473), convoked by Alfonso Carillo de Acuña, archbishop of Toledo (1446-82), and Sevilla (1478), called by Queen Isabel (r. 1474-1504) and her confessor Hernando de Talavera (1474-1504), who had studied theology at the University of Salamanca. ${ }^{77}$ These were followed by councils at Alcalá (1497) and Talavera (1498) under the leadership of Francisco Jiménez de Cisneros, head of the Franciscan Order in Castile and archbishop of Toledo (1494/95-1517). ${ }^{78}$

Bezares (Salamanca: Ediciones Universidad, 2006), 128. Of González's six works, only two, including Allegationes de potestate concilii, are found in the Salamancan library.

74. Hernández Montes, 58.

75. Annabel Brett, Liberty, Right and Nature: Individual Rights in Later Scholastic Thought (Cambridge: Cambridge University Press, 2003), 35.

76. Antonio Garcia y Garcia, Iglesia, Sociedad y Derecho (Salamanca: Universidad Pontificia de Salamanca, 1987), 203, 323.

77. Garcia y Garcia, Iglesia, Sociedad y Derecho, 202, 324. Carillo, whose uncle (also Alfonso Carillo) had attended the Council of Basel, had participated in a revolt, known as the Farce of Ávila, in 1465 against the government of Enrique IV (r. 1454-74) and in support of Isabel's full brother Alfonso.

78. Steven E. Turley, Franciscan Spirituality and Mission in New Spain, 1524-1599 (New York: Routledge, 2014), 18-20. 
Cisernos led a group of reforming Franciscans that included Juan de Zumárraga, "an unusually well-educated member of his province" and a teacher in the Franciscan studia generalia, a sort of university training. ${ }^{79}$ In the late 1520s Zumárraga became the first bishop, then archbishop of New Spain (Mexico). Carmen José Alejos-Grau has shown that Zumárraga had access to a library that included Gerson's De scientia mortis, which he copied almost entirely into his Regla cristiana (1546). ${ }^{80} \mathrm{He}$ also owned a copy of Thomas More's Utopia, which notably criticized the mendicant friars for their lifestyles and canon law for its human impositions on the church. ${ }^{81}$ On these points More echoed Gerson, who "did not seem to have much confidence in the evangelical power" of a life of poverty, "perhaps because it had been so often compromised and made an object of ridicule by the behavior of many in the orders of friars supposedly committed to it." ${ }^{22}$

Vasco de Quiroga, who had studied at the University of Salamanca and who became a judge in the Second Audiencia of New Spain in 1531, knew and worked with Zumárraga. Quiroga founded the first university in the colony, accumulated a large library, and helped bring the printing press to New Spain under the auspices of the influential Cromberger printers of Sevilla. ${ }^{83}$ Soon after the press arrived, Zumárraga had Juan Cromberger print Gerson's Tripartito de doctrina christiana a qualquier muy provechosa, one of his most frequently printed texts in the Spanish lands. ${ }^{84}$ Zumárraga believed that Gerson would be

79. Vicente Zavala, Fray Juan de Zumárraga (Durango: Vizcaya, 1985), 1:43. See also Neslihan Senocak, "The Franciscan studium generale: A New Interpretation," in Philosophy and Theology in the "Studia" of the Religious Orders and at Papal and Royal Courts (Turnhout: Brepols, 2012), 221-36.

80. Carmen José Alejos-Grau, "Filosofía Bajomedieval en Fray Juan de Zumárraga," in Caballeros, Monjas y Maestros en la Edad Media, ed. Lillian van der Walde, et al. (Mexico City: UNAM, 1996), 393.

81. Thomas More, Utopia (Basel: Johannes Froben, 1518), 7, 51.

82. Ryan, 48.

83. Fintan B. Warren, Vasco de Quiroga and His Pueblo-Hospitals of Santa Fe (Academy of American Franciscan History, 1963), 25; Victoria Ríos Castaño, "Not a Man of Contradiction: Zumárraga as Protector and Inquisitor of the Indigenous People of Central Mexico," Hispanic Research Journal, 13:1 (2012), 26-40, 26; Silvio Zavala, Sir Thomas More in New Spain: A Utopian Adventure of the Renaissance (London: Hispanic and Luso-Brazilian Councils, 1955), 10-11. The Cromberger family dominated printing in Sevilla up to the 1550s. Their success and proximity to the point of departure for the Americas facilitated their control of early printing in New Spain.

84. Wilkinson, ed., 375. 
an ideal guide for instructing missionary clergy in the Americas as well as those indigenous Americans who became proficient in the faith. ${ }^{85}$

After several years in the Americas, Quiroga wrote a report, Información en derecho sobre algunas provisiones del Real Consejo de Indias (1535), to Emperor Charles V (who was also Carlos I of Spain). ${ }^{86}$ In it he cites Gerson numerous times. Among the texts he cites are Gerson's De potestate ecclesiastica, indicating that he either had a copy with him, had learned or copied it at the University of Salamanca, or had access to it elsewhere. He quotes from Gerson's thirteenth consideration, which defines and divides the different sorts of laws of jurisdiction and government. Quiroga writes that the native peoples of New Spain were "barbarous [...] without any government among them that would make them free and good, as every rational human should have, of the three ways into which all good government is divided, as Aristotle observes and to which Jean Gerson, Christian doctor, refers, De origine juris, consideratione decima tercia." ${ }^{87}$ This statement is likely a reflection of his training at the University of Salamanca, which since 1422 had been a centre of humanistic Aristotelianism, having dropped the medieval glosses of the philosopher's works. ${ }^{88}$ Quiroga states that he had looked in New Spain for the good or bad forms of government that Aristotle described and Gerson mentioned. Not a single native had one of the three good forms, but they all had one of the three bad forms. Quiroga argued that Moctezuma, the Aztec ruler who presided over many of central Mexico's people when Hernán Cortés arrived in 1519, exercised all the conditions of bad government, not good government, "as Gerson says." Moctezuma was revered and adored, not as a human by free people but as a god by captive, oppressed, and servile people, the conditions of evil and tyranny. ${ }^{89}$

Quiroga cites Gerson's twelfth consideration later in his text, writing that divine providence and apostolic concession had given the New World to Charles V to teach its inhabitants. Citing Gerson, he argues that Christ, the

85. Blanca López de Mariscal, "La imagen del lector en las doctrinas cristianas," in Print Culture through the Ages: Essays on Latin American Book History, ed. Blanca López de Mariscal, Donna M. Kabalen de Bichara, and Paloma Vargas Montes (Newcastle upon Tyne: Cambridge Scholars, 2016), 54-55.

86. Vasco de Quiroga, "Información en Derecho," in Documentos, ed. Rafael Aguayo Spencer (Mexico City: Editorial Polis, 1939), 294.

87. Quiroga, 308.

88. Monsalvo Antón, 69-70.

89. Quiroga, 309. 
wisest legislator, gave the emperor, not the pope, civil and political dominion over all, believer or unbeliever, in order to establish justice and for the continuous edification of the church, "his beloved Spouse." ${ }^{90}$ This was a more Marsilian reading of Gerson than the author himself would have accepted, since he explicitly rejected the Paduan's imperial political reading of authority. Quiroga's interpretation of Gerson's De potestate ecclesiastica reveals how far the tract had come: originally intended to explain the spiritual authority of the entire congregatio fidelium assembled in council over the individual parts of the church, it was now employed as a neo-Aristotelian political tract to support the emperor's claim to rule over the previously unknown lands and peoples of the Americas.

\section{Conclusion}

Any survey of textual creation, exchange, and influence is likely to generate as many questions as answers, and that is certainly the case with Gerson. This is partly a consequence of manuscript and early print culture, which often saw multiple people involved in production, and partly a consequence of the nature of exchange among national and international networks of religious orders, universities, and church councils. There is much more work to be done in these areas in order to deepen and broaden our understanding of intellectual, social, and cultural developments. Nonetheless, it is possible to conclude that Gerson was more widely known in the Spanish kingdoms than previously thought and that his ideas were influential, particularly in respect to religious reform and political government. Gerson formed an important part of the conceptual world of Iberians from Juan de Segovia and Juan González to Vasco de Quiroga, even as interpretations and uses of his work shifted over time. 